2020, Volume 10, International Conference Globalization, Innovation and Development. Trends and Prospects (G.I.D.T.P.), pages: 395-406 | https://doi.org/10.18662/lumproc/gidtp2018/44

\section{New Genotypes of Castor Bean (Ricinus Communis L.) Productivity and Adaptability under Environmental Conditions in Southern Romania}

\author{
Rodica ST'URZU', \\ Cristina MELUCA ${ }^{2}$, \\ Sorina CERNAT ${ }^{3}$

\begin{abstract}
${ }^{1}$ SCDA Teleorman, Romania, rodicasturzu@yahoo.com
\end{abstract} \\ 2 SCDA Teleorman, Romania, \\ melucacristina@yahoo.com
}

3 University Valahia of Targoviste, Romania, cernat.sorina@yahoo.com
Abstract: This paper's aim is to identify new castor bean genotypes created at Agricultural Research and Development Station Teleorman in Southern Romania, with an improved productivity and adaptability to the area's environmental conditions. The study has dealt with 15 castor bean genotypes during three years' time (2013-2015). The experiment was made according to the fully randomized block method, in three replications. The results of the variance analysis have shown that there was a significant difference between the castor bean genotypes regarding the grain yield. The three years' average yield has shown that both lines T 647/02 (2711 $\mathrm{kg} / \mathrm{ha})$ and T $2410(2529 \mathrm{~kg} / \mathrm{ha})$ and the varieties Rivlas (2701 $\mathrm{kg} / \mathrm{ha}$ ) and Dragon (2451 kg/ha) have registered the highest productions, with significant production supplies (623-883 $\mathrm{kg} / \mathrm{ha})$ compare to the control variety Cristian $(1828 \mathrm{~kg} / \mathrm{ha})$. The crops stability was estimated by the means of the variability coefficient. The correlations analysis showed that there are strong relationships between productions and productivity elements: the seeds' weight per primary raceme $(\mathrm{r}=0,992)$, the capsules' weight per primary raceme $(r=0,925)$ and the number of seeds per primary raceme $(\mathrm{r}=0,841)$, as well as between the productivity elements: the capsules' weight and the seeds' weight per primary raceme $(r=0,929)$, the weight and the number of seeds per primary raceme $(r=0,832)$, the capsules' weight and the number of seeds per primary raceme $(\mathrm{r}=0,736)$. Also, there are significant positive correlations between the plant's height with the insertion height of the primary raceme $(\mathrm{r}=0,625)$ and the primary raceme length $(\mathrm{r}=0,625)$. There is a significant negative correlation between number of seeds per primary raceme and weight of a thousand seeds $(r=0,586)$. The results achieved in the study suggest that the castor genotypes are productive and adapted to the weather conditions in South Romania, recommended to be grown in this agricultural area.

Keywords: castor bean; yields; variability coefficient; correlations.

How to cite: Sturzu, R., Meluca, C., \& Cernat, S. (2020). New Genotypes of Castor Bean (Ricinus Communis L.)

Productivity and Adaptability under Environmental

Conditions in Southern Romania. In I. Panagoreț \& G.

Gorghiu (vol. ed.), Lumen Proceedings: Vol. 10. International Conference Globalization, Innovation and Development. Trends and Prospects (G.I.D.T.P.) (pp. 395-406). Iasi, Romania: LUMEN Publishing House.

https://doi.org/10.18662/lumproc/gidtp2018/44 


\section{Introduction}

Castor bean was cultivated for its oil in Egypt as long as 6000 years ago and from here it spread to the Mediterranean area, the Middle East, Asia, the Far East and India [5]. High genetic diversity of Ricinus communis in Etiopia show that species was original from Eastern Africa [15].

Castor bean is considered to be a drought hardy crop and growing very well under dry and warm regions having a rainfalls of 500-750 $\mathrm{mm}$.

It has a great capacity of adaptation and the ability to grow in the marginal places affected by drought and on saline soils [11].

The most important product of castor bean is oil from seed [9]. All over the world, traditional use has been for lighting and medicine [12], but the first has been replaced since the introduction of kerosene and electricity. Medicinal use of oil and other parts of the plant is still common, especially as a purgative (internal) and to treat various external wounds.

The castor bean (Ricinus communis L.) belongs to the family Euphorbiaceae and is an inedible oil crop, with diversified uses of its products, form fertilizer and fuel to silkworms feeding with plant leaves, and oil used in the manufacture of various cosmetic products, in the plastic industry, lubricants and manufacturing of biofuels [1].

Currently, oil is mainly produced as a basic material for industry, especially as a lubricant. The presscake is poisonous and cannot be fed to animals but is used as a fertilizer or a fuel. The castor oil also has commercial value for the manufacture of soap and also cosmetics products, margarine, lubricants, paints, dyes, inks, cold-resistant plastics, nylon, linoleum, pharmaceuticals and perfumes [8; 13]. The crop is also considered as a useful raw material for biodiesel production [6].

Castor bean is cultivated all over world, but about 97 percent of world production is made by India, China, Brazil, Ethiopia, Paraguay, Vietnam and Thailand, which are the main growers [3]. The castor is a decorative plant appreciated and cultivated in parks and gardens [11]. The castor bean can be grown in both irrigation and non-irrigation conditions, under various climatic conditions and on almost all soils types, provided they are well drained and less alkaline.

\section{Research Questions/Aims of the research}

Seed yield is a complex feature and represents the cumulative expression of several morphophysiological characteristics. Knowing the 
relationships between different characteristics is necessary for the program of improvement and selection of new genotypes [1].

This paper's aim is to identify new castor bean genotypes created at Agricultural Research and Development Station Teleorman in Southern Romania, with an improved productivity and adaptability to the area's environmental conditions.

\section{Research Methods}

The experimental material contained 12 castor bean genotypes by the improvement program at the Agricultural Research and Development Resort (ARDS) Teleorman, Romania. The research was conducted by ARDS Teleorman, in the southern Romanian area, during 2013-2015. Data presented in this paper is about the behavior of 15 castor bean genotypes ( 5 varieties, one of which was considered a control and 10 new castor bean lines) during 3 years, under different weather conditions regarding the temperatures and rainfalls, (parameters registered at the local weather station). The study was made after the completely randomized blocks design with three replicates, in $5 \mathrm{~m}$ length plots, 4 rows of plants on a distance of $70 \mathrm{~cm}$ inter-rows and $22 \mathrm{~cm}$ intra-row, wheat as a precursor plant (previous), without irrigation and fertilized using $300 \mathrm{~kg} / \mathrm{ha}$ (N20:P20:K0) complex chemical fertilizers. The sowing was manually executed on a 6-7 cm depth.

During the three research years, the genotypes have been analyzed both from the production ability point of view (yield/ha) and some morphoproductive characteristics: the plant's height, the insertion height of the primary raceme, primary raceme length, the number of stem nodes up to the primary raceme, number and weight capsules per primary raceme, number and weight seeds per primary raceme and weight of a thousand seeds.

All data achieved was statistically processed and interpreted through the variation analysis method [4], the variation coefficient and the correlation coefficient.

\section{Findings and Discussions}

The weather conditions during 2013-2015 were different from one year to another, having strong effects upon the main productivity elements of different studied castor bean genotypes. During vegetation time of the castor bean crops in 2013, the average monthly temperatures in April, May, June, July and August exceeded the multiannual average with $1.4^{\circ} \mathrm{C}, 2.3^{\circ} \mathrm{C}$, $1.4^{\circ} \mathrm{C}, 0.7^{\circ} \mathrm{C}$ and $2.3^{\circ} \mathrm{C}$, and in September the temperatures were $-0,2^{\circ} \mathrm{C}$ less 
than the monthly multiannual average. The maxim absolute temperatures registered during these months were $31.8^{\circ} \mathrm{C}$ on $27^{\text {th }}$ April, $33.2^{\circ} \mathrm{C}$ in May, $36.3^{\circ} \mathrm{C}$ in June, $38.7^{\circ} \mathrm{C}$ in July, $37.2^{\circ} \mathrm{C}$ in August and $31.7^{\circ} \mathrm{C}$ in September.

The rainfalls registered in May, June, July and September had a high quantitative distribution and variation $(85.4 \mathrm{~mm}, 142.0 \mathrm{~mm}, 87.6 \mathrm{~mm}, 73.8$ $\mathrm{mm})$, deviations from the multiannual monthly averages of $+25.1 \mathrm{~mm}$, $+71.8 \mathrm{~mm},+25.2 \mathrm{~mm},+28.0 \mathrm{~mm}$. In August, the humidity deficit was of $9.8 \mathrm{~mm}, 38.0 \mathrm{~mm}$ rainfalls in the last decade, and in the first and the second decade the rainfalls were almost non-existent, what caused a shorter maturity period for castor bean and a fast growing of the primary raceme. In September, there was an evolution of the rainfalls similar to the ones in August time. The rainfalls and temperatures' evolution during this time has influenced the castor bean sowing, in the way that it was 10-20 days delayed, as well as the rising, growing and development of the plants in vegetation time. As a consequence, most of the genotypes' grains yields were lower (Figures 1 and 2).

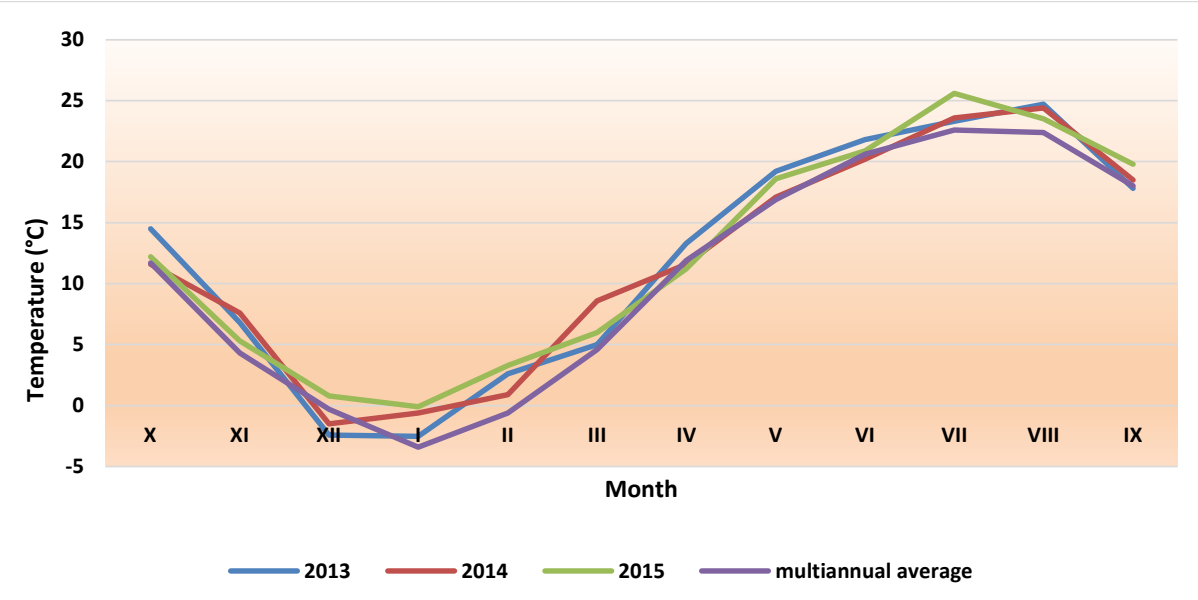

Figure 1. The monthly average temperature $\left({ }^{\circ} \mathrm{C}\right)$ during 2013-2014 


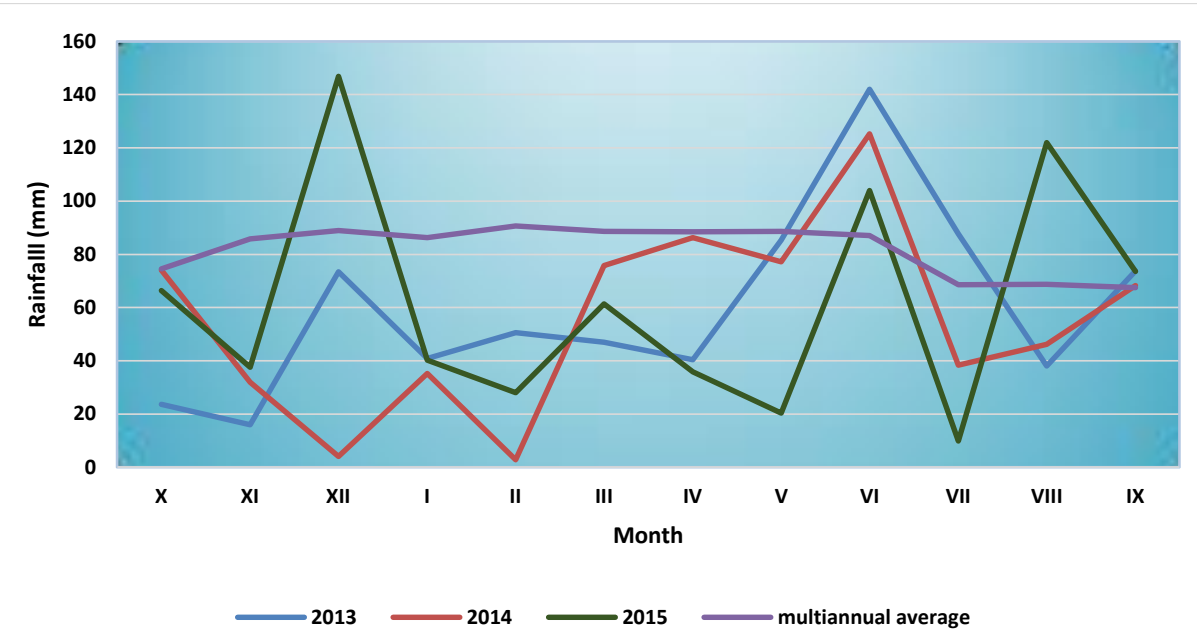

Figure 2. Rainfall during 2013-2015

The year 2014 was characterized by moderate average temperatures in April, May and June (deviations of $-0.3^{\circ} \mathrm{C},+0.5^{\circ} \mathrm{C}$ and $-0.4^{\circ} \mathrm{C}$ ) and higher ones in July and August $\left(+1.0^{\circ} \mathrm{C},+2.0^{\circ} \mathrm{C}\right)$, but higher rainfalls than the multiannual monthly average, relatively even distribution $(+45.4 \mathrm{~mm},+16.9$ $\mathrm{mm}$ and $+54.5 \mathrm{~mm})$ and poor rainfalls in July and August $(-23.8 \mathrm{~mm},-1.6$ $\mathrm{mm})$. There were heavy/torrential rains, accompanied by squalls that caused the tearing of leaves, bending the plants, vegetative growth and excessive branching, and also very good castor bean yields.

In 2015, the average monthly temperatures in May, June, July, August and September exceeded the annual average temperature with $+1,7^{\circ} \mathrm{C},+0.3^{\circ} \mathrm{C},+3.0^{\circ} \mathrm{C},+1.1^{\circ} \mathrm{C},+1.8^{\circ} \mathrm{C}$. Due to exceeding rainfalls in April $(30.4 \mathrm{~mm})$, the soil preparation and the sowing were delayed by almost 20 days. There were poor rainfalls in May $(-39.9 \mathrm{~mm})$ and July $(-52.0 \mathrm{~mm})$, that caused uneven rising and growing of plants, especially a poor growth and development of the productivity elements, having major negative effects over the production. In June, July, August and September, the rainfalls registered exceeded the monthly multiannual averages with $33.0 \mathrm{~mm}, 73.6$ $\mathrm{mm}, 28.4 \mathrm{~mm}$ that led to an almost normal vegetative growth of plants but they were not valued in order to increase the castor bean crop.

The results along the three years' study (2013-2015) revealed that the castor bean productivity varies from year to year, according to the genotype and the weather conditions, from $884 \mathrm{~kg} / \mathrm{ha}$ (Teleorman variety, 2015) to $3332 \mathrm{~kg} / \mathrm{ha}$ (Rivlas variety, 2014). 
Table 1. The average yields recorded by castor bean genotypes tested to ARDS Teleorman during 2013-2015

\begin{tabular}{|c|c|c|c|c|c|c|c|c|c|c|c|c|}
\hline \multirow[b]{2}{*}{$\begin{array}{l}\text { Genoty } \\
\text { pe }\end{array}$} & \multicolumn{4}{|c|}{2013} & \multicolumn{4}{|c|}{2014} & \multicolumn{4}{|c|}{2015} \\
\hline & $\begin{array}{c}\mathrm{kg} / \mathrm{h} \\
\mathrm{a}\end{array}$ & $\%$ & $\begin{array}{c}\text { Differe } \\
\text { nce } \pm \\
\text { control } \\
\mathrm{kg} / \mathrm{ha}\end{array}$ & $\begin{array}{l}\text { Signifi } \\
\text {-cance }\end{array}$ & $\mathrm{kg} / \mathrm{ha}$ & $\%$ & $\begin{array}{c}\text { Differ } \\
\text { ence } \\
\pm \\
\text { contr } \\
\text { ol } \\
\mathrm{kg} / \mathrm{ha}\end{array}$ & \begin{tabular}{|c} 
Sign \\
ifi- \\
canc \\
e
\end{tabular} & $\mathrm{kg} / \mathrm{ha}$ & $\%$ & \begin{tabular}{|c|} 
Differe \\
nce \pm \\
control \\
$\mathrm{kg} / \mathrm{ha}$
\end{tabular} & \begin{tabular}{|c|} 
Signi \\
fi- \\
canc \\
e
\end{tabular} \\
\hline Vlasca & 1620 & 86.9 & -244 & & 2092 & 95.1 & -108 & & 1404 & 98.9 & -16 & \\
\hline $\begin{array}{l}\text { Teleor } \\
\text { man }\end{array}$ & 1192 & 64.0 & -672 & & 1436 & 65.3 & -764 & & 884 & 62.3 & -536 & \\
\hline T 100 & 2928 & 157.1 & 1064 & *** & 3000 & 136.4 & 800 & $* * *$ & 1232 & 86.8 & -188 & \\
\hline Cristian & 1864 & 100.0 & 0 & & 2200 & 100.0 & 0 & & 1420 & $\begin{array}{r}100 . \\
0\end{array}$ & 0 & \\
\hline Dragon & 3112 & 167.0 & 1248 & *** & 3312 & 150.5 & 1112 & $* * *$ & 1528 & 65.4 & 108 & \\
\hline Rivlas & 3268 & 175.3 & 1404 & $* * *$ & 3332 & 151.5 & 1132 & $* * *$ & 1504 & $\begin{array}{r}105 . \\
9\end{array}$ & 84 & \\
\hline Т 2410 & 2944 & 157.9 & 1080 & *** & 3108 & 141.3 & 908 & *** & 1536 & $\begin{array}{r}108 . \\
2\end{array}$ & 116 & \\
\hline T 500 & 1764 & 94.6 & -100 & & 1764 & 80.2 & -436 & & 1016 & 71.6 & -404 & \\
\hline T 1270 & 2240 & 120.2 & 376 & $* * *$ & 2832 & 128.7 & 632 & $* * *$ & 1100 & 77.5 & -320 & \\
\hline $\begin{array}{l}\mathrm{T} \\
444 / 02\end{array}$ & 1952 & 104.7 & 88 & & 2260 & 102.7 & 60 & & 1048 & 73.8 & -372 & \\
\hline $\begin{array}{l}\mathrm{T} \\
647 / 02 \\
\end{array}$ & 3124 & 167.6 & 1260 & $* * *$ & 3172 & 144.2 & 972 & $* * *$ & 1836 & $\begin{array}{r}129 . \\
3\end{array}$ & 416 & $* * *$ \\
\hline $\begin{array}{l}\mathrm{T} \\
128 / 01\end{array}$ & 1804 & 96.8 & -60 & & 2324 & 105.6 & 124 & & 1036 & 73.0 & -384 & \\
\hline Т 12 & 2468 & 132.4 & 604 & *** & 2668 & 121.3 & 468 & *** & 936 & 65.9 & -484 & \\
\hline T 1369 & 1964 & 105.6 & 100 & & 2884 & 131.1 & 684 & $* * *$ & 1196 & 84.2 & -224 & \\
\hline T 1322 & 2184 & 117.2 & 320 & *** & 2924 & 132.9 & 724 & *** & 996 & 70.1 & -424 & \\
\hline $\begin{array}{l}\text { LSD } \\
5 \% \\
\end{array}$ & 139 & & & & 152 & & & & 150 & & & \\
\hline $\begin{array}{l}\text { LSD } \\
1 \% \\
\end{array}$ & 188 & & & & 204 & & & & 201 & & & \\
\hline $\begin{array}{l}\text { LSD } \\
0,1 \%\end{array}$ & 250 & & & & 272 & & & & 268 & & & \\
\hline
\end{tabular}

Production increases significantly according to the statistics, compared to the average value of Cristian witness soil for genotypes $\mathrm{T}$ 647/02 (2013, 2014, 2015), Rivlas (2013, 2014), Dragon (2013, 2014), T 2410 (2013, 2014), T100 (2013, 2014), T12 (2013, 2014) and T1322 (2013, 
2014) (Table 1). The low yields were in 2015, a dry year during the formation and development of the castor bean productivity elements, and the high yields were achieved in 2014, an almost regular year regarding the temperatures and the rainfalls for castor bean yields (Figure 3).

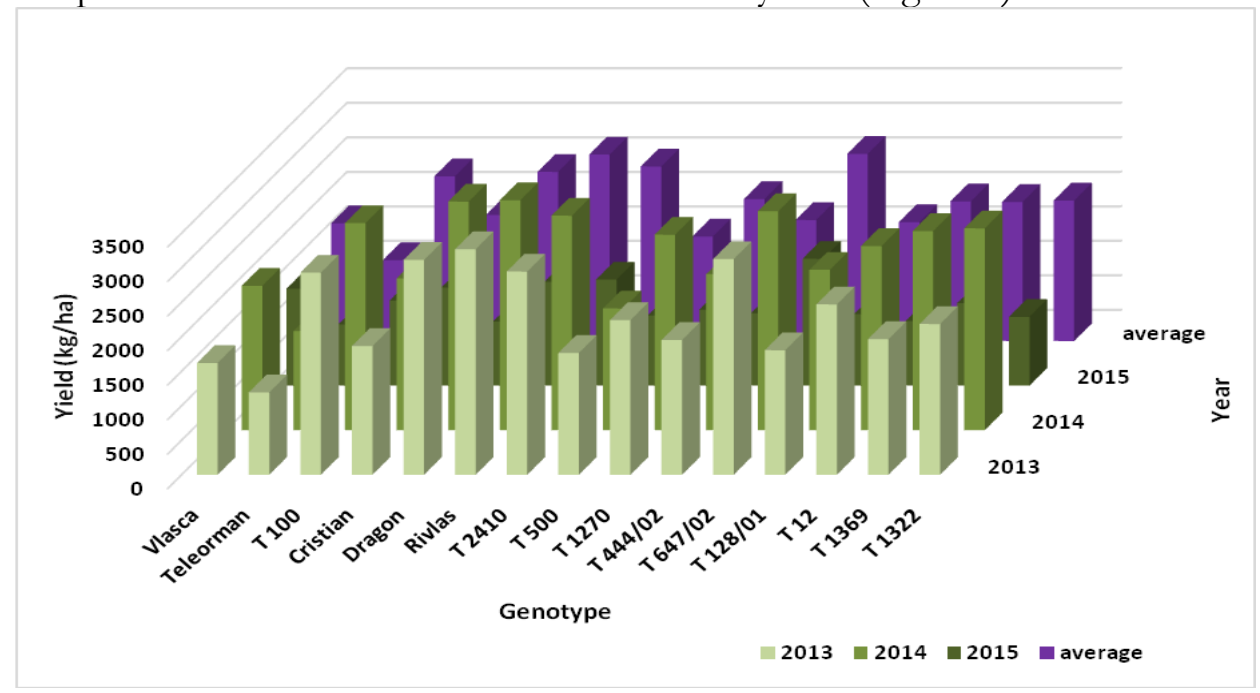

Figure 3. Yields castor bean genotypes tested during 2013-2015

Regarding the average yields for the castor bean tested genotypes during the analyzed period of time (2013-2015), genotypes T 647/02 (2711 $\mathrm{kg} / \mathrm{ha})$, Rivlas (2701 kg/ha), Dragon (2651 kg/ha), T 2410 (2529 kg/ha), T 100 (2387 kg/ha), T 1270 (2057 kg/ha), T 1322 (2035 kg/ha), T 12 (2024 $\mathrm{kg} / \mathrm{ha}$ ) and T 1369 (2015 kg/ha). These genotypes' production supplies statistically provided were between 187 and $883 \mathrm{~kg} / \mathrm{ha}$, compared to the control (Tables 1 and 2).

In Southern Italy, during 2010-2011, four castor genotypes obtained grain yields between $720-7350 \mathrm{~kg} / \mathrm{ha}$, which shows the variety's influence on the production [2].

Since castor bean is a moisture sensitive crop productivity is directly correlated to the level of rainfall [5].

Analyzing the significances reveals that, although 9 genotypes proved to be significantly superior to the control along the 3 years of research, because of the great fluctuations from one year to another, only 4 genotypes (T 647/02, Rivlas, Dragon and T 2410) will be superior in the future, too.

Analyzing the variation coefficients for each of the tested genotypes reveals that varieties Vlassca, Cristian and Teleorman have had the least 
variations of production along the three years $(\mathrm{Cv}=16.9-19.3 \%)$ that reveals that they have the greatest adaptability to the weather conditions in the area.

Table 2. Average yield registered by castor bean genotypes tested during 2013-2015

\begin{tabular}{|c|c|c|c|c|c|c|}
\hline \multirow[b]{2}{*}{ Genotype } & \multirow{2}{*}{$\begin{array}{l}\text { Yield } \\
\mathrm{kg} / \mathrm{ha}\end{array}$} & \multirow{2}{*}{$\begin{array}{c}\text { Yield } \\
\text { relative } \\
\%\end{array}$} & \multirow{2}{*}{$\begin{array}{c}\text { Difference } \\
\pm \text { control } \\
\mathrm{kg} / \mathrm{ha}\end{array}$} & \multicolumn{2}{|c|}{ The significance } & \multirow{2}{*}{$\begin{array}{c}\mathrm{CV} \\
\%\end{array}$} \\
\hline & & & & $\begin{array}{l}\text { to } \\
\text { error }\end{array}$ & $\begin{array}{c}\text { to } \\
\text { interaction }\end{array}$ & \\
\hline Vlasca & 1705 & 93.3 & -123 & & & 16.9 \\
\hline Teleorman & 1171 & 64.0 & -657 & & & 19.3 \\
\hline $\mathrm{T} 100$ & 2387 & 130.6 & 559 & $* * *$ & & 34.2 \\
\hline $\begin{array}{ll}\text { Cristian } & - \\
\text { control } & \end{array}$ & 1828 & 100.0 & 0 & & & 17.5 \\
\hline Dragon & 2651 & 145.0 & 823 & $* * *$ & $* *$ & 30.1 \\
\hline Rivlas & 2701 & 147.8 & 873 & $* * *$ & $* *$ & 31.4 \\
\hline T 2410 & 2529 & 138.4 & 701 & $* * *$ & $*$ & 27.9 \\
\hline T 500 & 1515 & 82.9 & -313 & & & 23.3 \\
\hline T 1270 & 2057 & 112.5 & 229 & $* * *$ & & 34.9 \\
\hline $\mathrm{T} 444 / 02$ & 1753 & 95.9 & -75 & & & 29.3 \\
\hline $\mathrm{T} 647 / 02$ & 2711 & 148.3 & 883 & $* * *$ & $* *$ & 22.8 \\
\hline T 128/01 & 1721 & 94.2 & -107 & & & 30.7 \\
\hline T 12 & 2024 & 110.7 & 196 & $* * *$ & & 38.2 \\
\hline T 1369 & 2015 & 110.2 & 187 & $* * *$ & & 34.3 \\
\hline \multirow[t]{2}{*}{ T 1322} & 2035 & 111.3 & 207 & *** & & 39.0 \\
\hline & $\begin{array}{c}\text { to } \\
\text { erorr }\end{array}$ & $\begin{array}{c}\text { to } \\
\text { interaction } \\
\mathrm{Vx} \mathrm{Y} \\
\end{array}$ & & & & \\
\hline $\begin{array}{l}\text { LSD for } \\
\mathrm{P}<0.05\end{array}$ & 90 & 568 & & & & \\
\hline $\begin{array}{l}\text { LSD for } \\
\mathrm{P}<0.01\end{array}$ & 119 & 765 & & & & \\
\hline $\begin{array}{l}\text { LSD for } \\
\mathrm{P}<0.001\end{array}$ & 153 & 1017 & & & & \\
\hline
\end{tabular}

Results following analysis of tested castor bean genotypes production variance during three years and the varying interaction $\mathrm{x}$ years are presented in Table 3 . The experimental value of $F$ evidence presents very significant effects between variants and other interactions for variants $\mathrm{x}$ years which reveal that the genotypes' very different reaction towards the different years of research conditions. 
Table 3. ANOVA for yield over three years

\begin{tabular}{|l|l|l|l|l|l|}
\hline Source of variation & SS & FD & SS/FD & F to E & F to s2 V x Y \\
\hline Blocks & 2.23 & 6 & & & \\
\hline Years & 11845444.70 & 1 & & & \\
\hline Variants & 2030.28 & 23 & 88.27 & $55.16^{* * *}$ & $0.93(2.00-2.70)$ \\
\hline Var. $x$ years & 2174.75 & 23 & 94.55 & $59.09^{* * *}$ & \\
\hline Error & 230.47 & 144 & 1.60 & & \\
\hline Total & 11849882.43 & 197 & & & \\
\hline
\end{tabular}

$* * * \mathrm{p}<0.001$

Studying the correlations between production and the main morphoproductive characters, as well as between characters, reveals that the most relevant (positive and very significant) are: between yield and weight seeds per primary raceme $\left(\mathrm{r}=0,992^{* * *}\right)$, weight and number of seeds per primary raceme $\left(r=0,832^{* * *}\right)$, weight capsules and number of seeds per primary raceme $\left(r=0,736^{* *}\right)$, (Table 4). Similar values of the correlation coefficients were found by [1], [7], [10], [13], and [14]

The results state the fact that these characters are main elements of the castor bean productivity, and the relationship between them may be considered as criteria of selection for raising the productivity in the improvement program for this variety.

Also, there are significant positive correlations between height plant and height insertion of the primary raceme $\left(\mathrm{r}=0,625^{* *}\right)$ and the primary raceme length $\left(\mathrm{r}=0,625^{* *}\right)$, stated by [9] and [10], too.

A significant negative correlation was identified between the number of seeds per primary raceme and the weight of a thousand seeds ( $\mathrm{r}=$ $0,586^{* *}$. Similar values of the correlation coefficients were found by [1] and [10].

Table 4. Correlation coefficients between the main characters of tested morphoproductive castor bean genotypes

\begin{tabular}{|l|l|l|l|l|l|l|l|}
\hline \multicolumn{1}{|c|}{ Character } & Yield & $\begin{array}{c}\text { Hight } \\
\text { plant }\end{array}$ & $\begin{array}{c}\text { Hight } \\
\text { insertion } \\
\text { of } \\
\text { primary } \\
\text { raceme }\end{array}$ & $\begin{array}{c}\text { Length } \\
\text { of } \\
\text { primary } \\
\text { raceme }\end{array}$ & $\begin{array}{c}\text { Weight } \\
\text { of } \\
\text { capsules } \\
\text { on } \\
\text { primary } \\
\text { raceme }\end{array}$ & $\begin{array}{c}\text { Number } \\
\text { of seeds } \\
\text { on } \\
\text { primary } \\
\text { raceme }\end{array}$ & $\begin{array}{c}\text { Weight } \\
\text { of seed } \\
\text { on } \\
\text { primary } \\
\text { raceme }\end{array}$ \\
\hline Height plant & 0,133 & $\mathrm{x}$ & & & & & \\
\hline $\begin{array}{l}\text { Hight } \\
\text { insertion of }\end{array}$ & $0,406^{*}$ & $0,625^{* *}$ & $\mathrm{x}$ & & & & \\
\hline
\end{tabular}




\begin{tabular}{|c|c|c|c|c|c|c|c|}
\hline $\begin{array}{l}\text { primary } \\
\text { raceme }\end{array}$ & & & & & & & \\
\hline $\begin{array}{l}\text { Length of } \\
\text { primary } \\
\text { raceme }\end{array}$ & $0,214^{*}$ & $0,625^{* *}$ & 0,162 & $\mathrm{x}$ & & & \\
\hline $\begin{array}{l}\text { Weight of } \\
\text { capsules on } \\
\text { primary } \\
\text { raceme }\end{array}$ & $0,925^{* * *}$ & 0,162 & $0,385^{*}$ & 0,180 & $\mathrm{x}$ & & \\
\hline $\begin{array}{l}\text { Number of } \\
\text { seeds on } \\
\text { primary } \\
\text { raceme }\end{array}$ & $0,841^{* * *}$ & 0,185 & $0,458^{* *}$ & $0,265^{*}$ & $0,736^{* * *}$ & $\mathrm{x}$ & \\
\hline $\begin{array}{l}\text { Weight of } \\
\text { seed on } \\
\text { primary } \\
\text { raceme }\end{array}$ & $0,992^{* * *}$ & 0,148 & $0,449 * *$ & 0,192 & $0,929 * * *$ & $0,832^{* * *}$ & $\mathrm{x}$ \\
\hline $\begin{array}{l}\text { 1000-seeds } \\
\text { weight }\end{array}$ & $-0,088$ & $-0,063$ & 0,125 & $-0,193$ & 0,054 & $-0,586^{\circ \circ}$ & $-0,049$ \\
\hline
\end{tabular}

$\left.{ }^{*}\right)$ positive and ${ }^{\circ}$ ) negative correlation coefficients significant at $\mathrm{p}<0.05$ level

${ }^{* *}$ ) positive and ${ }^{\circ \circ}$ ) negative correlation coefficients significant at $\mathrm{p}<0.01$ level

$\left.{ }^{* * *}\right)$ positive and ${ }^{\circ o \circ}$ ) negative correlation coefficients significant at $\mathrm{p}<0.001$ level

\section{Conclusions}

The research period (2013-2015) was characterized from the weather conditions (air temperatures) point of view, but mostly from the water point of view (rainfalls), very different from one year to another. The main factor to influence the level and stability of the castor bean production is the quantity and distribution of the rainfalls along the vegetation period. Average productions of over $2000 \mathrm{~kg} / \mathrm{ha}$ were achieved by new lines $\mathrm{T}$ 647/02 and T 2410, as well as varieties Rivlas and Dragon. The correlations analysis revealed that the strongest relationships are the ones between yield and the seeds' weight, also the capsules per primary raceme and the number of seeds per primary raceme, as well as between the productivity elements: the capsules' weight and the seeds' weight per primary raceme, the seeds' weight and number per primary raceme, the capsules' weight and the number of seeds per primary raceme. Also, there are significant positive correlations between the plant's height and the insertion height per primary raceme and the primary raceme's length and the 1000 seeds weight. The results in the study reveal that the castor bean genotypes are productive and adapted to the weather conditions in South Romania, to be recommended in order to be grown in this agricultural area. 
The richest crops were in 2014, a year that was favorable (normal) both regarding the warm temperatures and the rainfalls and the poorest crops were in 2015, a year of dryness and scorching heat during the productivity elements' formation period and the accumulation of reserve substances in castor beans.

\section{References}

[1]. Ahmed HM, Sarwar G, ul Haq MA. Genetic variability and interdependence of morphological traits in castor bean (Ricinus communis L.) mutants. Songklanakarin Journal Science Technology. 2012; 34(3): 279-286.

[2]. Atanasi U, Sortino O, Cosentino SL, Patanè C. Seed yield and oil quality of perennial castor bean in Mediterranean environment. International Journal of Plant Production. 2015; 9(1): 99-116.

[3]. ***. Food and Agriculture Organization of United Nations; 2008. Available from: http://www.fao.org/3/a-i0100e.pdf [Accessed 7th February 2020].

[4]. Ceapoiu N. Metode statistice aplicate în experiențele agricole și biologice. București: Editura Agro-Silvică; 1968.

[5]. Cheema NM, Farooq U, Shabbir G, Shah MKN, Musa DM. Prospects of castor bean cultivation in rainfed tract of Pakistan. Pakistan Journal Botanic. 2013; 45(1): 219-224.

[6]. Forero CLB. Biodiesel from castor oil: a promising fuel for cold weather. Renewable Energy and power Quality Journal. 2005: 1(3): 59-62.

[7]. Goodarzi F, Hassani A, Darvishzadeh R, Hatami Maleki H. Genetic variability and traits association in castor bean (Ricinus communis L). Genetika. 2015; 47(1): 265-274.

[8]. Goodarzi F, Darvishzadeh R, Hassani A, Hassanzaeh A. Study on genetic variation in Iranian castor bean (Ricinus communis L.) accessions using multivariate statistical techniques. Journal of Medicinal Plants Research. 2011; 5(21): 5254-5261.

[9]. Msaakpa TS, Obasi MO. Correlated studies between growth and yield characters of castor bean (Ricinus communis L.). International Journal of Scientific and Research Publications. 2014; 4(7): 1-10.

[10]. Da Silva AR, Silva SA, Almeida V. de O, Araujo G. de M, Ledo A. da S. Correlations and track analysis for morphoagronomic descriptors in pedigriu and parental lines of castor bean. Ciência Rural. 2017; 4(4): 1-7.

[11]. Sowmya P, Vanaja M, Sathish P, Vijay Kumar G, Razak A, Vaiodya S, Anitha Y, Satyavanthi P. Variability in Physiological and Yield Performance of Castor (Ricinus communis L.) Genotypes under Rainfed Condition of Alfisols. International Journal of Plant Breeding and Genetics. 2016; 10(1): 52-57.

[12]. Sturzu R, Nistor T, Melucă C, Bodescu F, Negrilă M, Ene AM. Ricinul „Palma lui Christos". București, Romania: Ed. New Agris; 2014: 1-61.

[13]. Tewari N, Mishra A. Correlation and Path Coefficient Analysis of castor (Ricinus communis L.) in non-traditional area of central Uttar Pradesh. 
Internacional Journal of Genetic Engineering and Biotechnology. 2013; 4(1): $1-9$.

[14]. Torres FE, Teodoro PE, Ribeiro LP, Correa CCG, Hernandes FB, Fernandes RL, Gomes A.C. and Lopes K.V. 2015. Correlations and path analysis on oil content of castor genotypes. Bioscience Journal, Uberlândia, 31(5): 1363-1369.

[15]. Vavilov NI. The origin, variation, immunity and breeding of cultivated plants. Waltham, MA: Chronica Botanica. 1951; 13: 1-366. 